Relations industrielles

Industrial Relations

\title{
L'avenir du syndicalisme, par Armand Capacci, Collection les Grands Problèmes, Hachette, Paris, 1967, 267 pages.
}

\section{L.-René Parenteau}

Volume 23, numéro 1, 1968

URI : https://id.erudit.org/iderudit/027873ar

DOI : https://doi.org/10.7202/027873ar

Aller au sommaire du numéro

Éditeur(s)

Département des relations industrielles de l'Université Laval

ISSN

0034-379X (imprimé)

1703-8138 (numérique)

Découvrir la revue

Citer ce compte rendu

Parenteau, L.-R. (1968). Compte rendu de [L'avenir du syndicalisme, par Armand Capacci, Collection les Grands Problèmes, Hachette, Paris, 1967, 267 pages.] Relations industrielles / Industrial Relations, 23(1), 177-177.

https://doi.org/10.7202/027873ar

Tous droits réservés @ C Département des relations industrielles de l'Universite Laval, 1968
Ce document est protégé par la loi sur le droit d'auteur. L’utilisation des services d'Érudit (y compris la reproduction) est assujettie à sa politique d'utilisation que vous pouvez consulter en ligne.

https://apropos.erudit.org/fr/usagers/politique-dutilisation/ 


\section{RECENSIONS}

L'avenir du syndicalisme, por Armand $\mathrm{Ca}$ pocci, Collection les rands Problèmes, $\mathrm{Ha}$ chette, Paris, 1967, 267 pages.

Des premières organisations syndicales françaises, à travers l'évolution du syndicalisme français et étranger, Armand Capocci retrace et formule la vocation révolutionnoire du syndicalisme. Por une interprétation des faits rapide et parfois décousue, il pose les jalons de la lutte internationale des closses, lutte qui se traduit par une opposition parfois violente et anarchique ou pouvoir potronal et étatique.

L'auteur rapproche d'une façon assez bizarre les aspirations ouvrières ò la lutte des classes au sens marxiste du terme, il tente parfois d'identifier l'apolitisme de l'action syndicale ò l'anarchisme pur et simple, et il pose !'avenir du syndicalisme en ces termes: " Le syndicalisme est, par essence, fait pour conquérir et non pour accepter *

Poser l'action syndical en termes de lutte des closses ne fait-il pas un peu vieillot et lo peur morbide de l'intégration du syndicalisme ou système par la participation ne risque-t-elle pas de paralyser cette action? Voilò des questions qui ne sont pas posées dons cet ouvrage. La lutte des classes y est posé comme une base fondamentole et la conception de la participation reflète des positions cégétistes évidentes

Si oprès les luttes mémorables que le syndicalisme international a soutenues pour se faire reconnaître et pour se faire occorder un statut presque égal oux autres institutions capitalistes contemporaines, pourquoi refuserait-il aujourd'hui d'utiliser les droits que lui accorde cette reconnaissance? Si le syndicalisme, pour être révolutionnaire, doit être onarchique, nous n'en scmmes plus. Le syndicalisme sera réellement révolutionnaire s'il réussit d'abord ò faire l'unité des travailleurs, $s^{\prime} i l$ cesse ses querelles intestines pour mettre en commun toutes ses ressources, si peu importantes soient-elles, ofin de porticiper réellement. Cette participation, bien qu'elle ne lui accorde pas le pouvoir comme le regrette $M$. Capocci, lui accorde un droit manifeste de discuter et d'être consulté. S'il ne veut pas rester un parent pauvre dans cette discussion, le syndicalisme doit mettre sur pied des équipes de chercheurs qui apporteront ò la table des négo. ciations des propositions clairement formulées et fondées sur des calculs qui éviteront l'approximation et les tatonnements.

L'auteur le dit justement, il reste deux options ou syndicalisme, soit reconnaitre le système social et s'efforcer de le corriger. soit le réfuter et mettre toute son énergie ou service de la révolution. Cependant, nous semble-t-il, avont de lancer la classe ouvrière dans une aventure où elle risque fort de crever, il conviendrait d'utiliser à fond les nouveaux mécanismes de participation et $d^{\prime} y$ mettre autant d'effort et de coeur qu'on en a mis dans la revendication jusqu'ici. II reste un impondérable, la prise de conscience de leurs responsabilités sociales par les leaders et chefs syndicaux.

\section{L.-René PARENTEAU}

The New Perspectives in Collective Bargoining, by Don R. Sheriff, Editor, Center for Labor and Management, College of Business Administration, The University of lowa, lowo City, lowa, 1966, 41 pages

This booklet covers the controversial oreo embracing the issue of government intervention in the bargaining process. It involves the comprehensive scope of the limits of labor-management relations, work stoppages, the necessities of the public welfare, national defense, and the contours of the free enterprise system.

The range of the discussion is indicated by the presentations of the points of view and arguments of important experienced leaders from the fields of labor, industry and the public represented by an officer of the United States Federal Mediation and Conciliation Service and a journalist from on outstanding newspaper. Each of the four contributions is introduced with a preliminary onalysis by university faculty members.

Necessarily, one's reaction to the separate versions depends upon the interest of the reader. Yet the overage citizen who is affected by a serious work stoppage in an essential industry is concerned with some. governmental instrumentality which will restone normal conditions.

What should not be overlooked, however, is the all inclusive coverage of the concept 